how long this immunity lasts in animals thus vaccinated against rinderpest. It has been ascertained that neither birds, such as fowls, doves, pigeons, guinea-fowls, and cranes are susceptible to the pest. An eagle and a secretary-bird were fed for weeks on intestines taken from rinderpest animals, but absolutely no ill-effect followed. Dogs and donkeys are also immune, as are likewise mice, guinea-pigs, and rabbits ; to pigs only, so far, does it appear possible to transmit the infection. In conclusion, Dr. Koch's investigations with Dr. Edington's plague microbe have proved that the latter is not the cause of rinderpest.

\section{NOCTURNAL AND DIURNAL CHANGES IN THE COLOURS OF CERTAIN FISHES AND OF THE SQUID (LOLIGO), WITH NOTES ON THEIR SLEEPING HABITS. ${ }^{1}$}

WHILE investigating the nocturnal habits and colours of some of our native marine fishes, in 1885 to 1887 , at Wood's Holl, Mass., in the laboratory of the U.S. Fish Commission, of which I had charge at that time, I made the unexpected discovery that a number of species had the peculiar habit of assuming, while sleeping, a style of colouration quite unlike that seen in the daytime. Numerous other duties prevented me from making as many observations of this kind as I wished, at that time, nor have I since had opportunities to continue them. Therefore I have decided to publish these incomplete observations, with the hope of inducing other naturalists to continue such studies in some of the various zoological stations that are now established.

Most of my observations were made late at night, between midnight and 2 o'clock a.m., when everybody else had retired. The gas jets near the aquaria were turned down so low as to give barely light enough to distinguish the forms and colours of the fishes. Under these conditions, by using great care not to cause any jar of the floor, nor sudden movements of any kind, I succeeded in observing many species asleep. Most fishes sleep very lightly, and are aroused by almost imperceptible vibrations of the air or water. Some of these fishes took unexpected attitudes while asleep.

In many cases the change of colour from that seen while awake, or in the daytime, consisted in a simple increase in the depth or intensity of the colours, the pattern of colours remaining the same. This was the case with several species of flounders. Those that are spotted or mottled with dark pigment showed their markings much more strongly, or in greater contrast with the ground-colour, than by day. Several species of minnows (Fundulus), which are marked either with longitudinal or transverse dark bands, have these markings more decidedly black and better defined than by day. The same is true of the king-fish (Menticirrus nebulosis), in which there are obliquely transverse dark stripes that come out more strongly at night than by day.

The black sea-bass (Serranus furous) and the sea-robins (Prionotus palmipes and P. evolans) presented the same phenomena. Several species of trout (Salvelinus fontinalis, \&c.) were observed to become much darker at night than in the daytime, but I was not sure that any of those observed were asleep at the time.

It is well known that trout, flounders, and some other fishes are able to change their colours, even in the daytime, according to the colour of their surroundings. Therefore a darkening of the colours at night is to be expected, even if not asleep. But in all the cases mentioned above the nocturnal change of colour is of a protective character.

Other fishes, however, show much more remarkable changes. Among these the scup or porgy (Stenotomus chrysops) is one of the best examples. This fish, when active in the daytime, usually has a bright silvery colour with iridescent tints. But at night, when asleep, it has a dull bronzy ground-colour, and the body is crossed by about six transverse black bands. When one of these fishes, with this colouration, was awakenedby suddenly turning up the gas, it immediately assumed the bright silvery colours belonging to its daytime dress. This experiment was repeated many times, on different individuals, with the same

1 Abstract of a paper read before the American Morphological Society, December 30,1896 . These obiervations were also communicated to the Connecticut Academy of Sciences, in 1888 , but were not published. (Reprinted from the American Journal of Science for February.) result. As this fish naturally rests among eel-grass and sea-weeds, the protective character of its nocturnal colours is obvious.

A common file-fish (Monacanthus, sp.) was observed that presents a very decided change in colour pattern. This species, in the daytime, is mottled with brown and dark olive-green, and the fins and tail are a little darker than the body, bu when asleep, at night, its body becomes pallid grey or nearly white, while the fins and tail become decidedly black. These colours are decidedly protective at night, or in a feeble light, among rocks and weeds, where it lives. This and other species of file-fishes, when sleeping, would usually rest on the bottom with the back leaning against the glass of the aquarium, or against a stone at a considerable angle.

The common tautog or black fish (Tautoga onitis) has the curious habit of resting upon one side, half-buried among gravel, or partly under stones, and is often curved in strange positions. It is easy to imagine that the flounders originated from some symmetrical ancestral form that acquired, like the tautog, the habit of resting upon one side, at first only when sleeping, but afterwards continually, owing to the greater protection that this habit and its imitative colouration afforded. The one-sided colouration and the changes in the position of the eyes, \&c., would gradually follow in accordance with wellknown laws of evolution.

The common squid (Loligo Pealei) was observed sleeping on several occasions. At such times it rests in an inclined position, on the tip of its tail and on the basal parts of the arms, which are bunched together and extended forward, so that the head and anterior part of the body are raised from the bottom, so as to give room for breathing. The siphon tube is then turned to one side. Under these circumstances the colour is darker and the spots more distinct than when it is active, owing to the expansion of the brown and purple chromatophores.

A. E. VERRILI.

\section{UNIVERSITY AND EDUCATIONAL INTELLIGENCE}

OxForD. - The Junior Scientific Club met on Wednesday, March 3, Mr. A. W. Brown (Ch. Ch.), President, in the chair. Prof. Ray Lankester exhibited and described a specimen of Cladosclache and a cast of a restoration of the skull of Thylacoleo. Both specimens have recently been added to the museum. Dr. J. S. Haldane read a paper on "The Causes of Absorption of Oxygen by the Lungs," which was followed by a lengthy and animated discussion.

CAmbridge. - Dr. S. H. Vines, F.R.S., has been appointed by the Council of the Senate a Governor of the Oxford High School for boys.

The valuable collection of Pyrenean and Alpine plants, numbering about 4000 , made by the late Mr. Charles Packe, of Christ Church, Oxford, has been presented by his widow to the University Herbarium.

Mr. William Lampson, who died recently at Le Roy, near Rochester, in the State of New York, left the bulk of his estate, valued at about one million dollars, to Yale University, from which he graduated in 1862 .

The Norwegian Parliament has unanimously decided to appoint Dr. Nansen to a Chair of Zoology in the University of Christiania. It is understood that the duties of the Chair will not interfere with any further explorations of the Arctic or Antarctic regions which Dr. Nansen may be disposed to undertake.

To city and county authorities seeking a means of com memorating the sixtieth year of the Queen's reign, we commend the example of the Royal Reception Committee at Sheffield. This Committee was entrusted with the duty of preparing for the Queen's visit to that city on May 21 , and at the same time of arranging a suitable mode of commemorating the Diamond Jubilee, and they have decided that the endowment of the Sheffield University College is the best object. For this end the sum of $30,000 \%$. is still required, and the Committee have resolved to invite subscriptions through the Mayor, the Duke of Norfolk. 